\title{
Aplikasi Regresi Linier Berganda Pada Hubungan Kepadatan Hunian Dan Perilaku Menguras Bak Mandi Dengan Kejadian Penyakit Malaria Di Indonesia
}

\author{
Endang Yuswatiningsih, S.Kep.,Ns.,M.Kes \\ STIKES Insan Cendekia Medika Jombang
}

\begin{abstract}
The purpose of this research is to modelize the relationship between density residential and the behavior of tub drain with the incidence of malaria in Indonesia. This research used multiple linear regression method with 1 dependent variable and 2 independent variables. The assumption multiple linier regression is an error followed a normal distribution, error variance is homoskedastisitas, no autocorrelation problem and there was no problem of multicollinearity between independent variables. The result showed that all assumptions of multiple linier regression were fulfilled. Overall test results by using $\mathrm{F}$ statistic was obtained value of $\mathrm{p}=0,001<0,05$ (alpha) it meant that at least one variable density residential or behavior of tub drain which had a significant effect on the incidence of malaria. The test results partly by using $t$ statistics was obtained value of $\mathrm{p}$ variable density residential was $0,001<0,05$ which meant that density residential had effect on the incidence of malaria and value of $p$ for the behavior of tub drain variable was $0,980>0,05$ which meant that the behavior tub drain had no effect on the incidence of malaria
\end{abstract}

\section{Keywords : multiple linier regression, density residential, behavior, malaria}

\section{Pendahuluan}

Pembangunan kesehatan sebagai salah satu upaya pembangunan yang berkesinambungan merupakan rangkaian pembangunan yang menyeluruh, terarah, dan terpadu untuk mencapai tujuan nasional. Pembangunan kesehatan merupakan upaya untuk meningkatkan kesadaran, keinginan, dan kemampuan hidup sehat bagi setiap orang agar terwujud derajat kesehatan masyarakat yang setinggi-tingginya, sebagai investasi bagi pembangunan sumber daya manusia yang produktif secara sosial dan ekonomi. Upaya kesehatan perseorangan masyarakat merupakan kegiatan untuk mewujudkan derajat kesehatan yang setinggi-tingginya bagi masyarakat (Profil Kesehatan Indonesia, 2013). Peningkatan pemerataan pelayanan kesehatan kepada masyarakat merupakan upaya pelaksanaan pembangunan dalam bidang kesehatan. Pembangunan kesehatan yang telah dilaksanakan telah berhasil untuk meningkatkan status kesehatan masyarakat secara bermakna, meskipun masih banyak penduduk yang belum dapat menikmatinya. Hal itu dikarenakan keberhasilan pembangunan dalam bidang kesehatan ditentukan oleh ada tidaknya pedoman penyelenggaraan pembangunan kesehatan.

Salah satu bagian yang sangat penting dari kesehatan adalah kesehatan lingkungan, hal ini jelas terdapat dalam undang-undang Nomor 36 tahun 2009 tentang kesehatan yang menyebutkan bahwa untuk mewujudkan kualitas lingkungan yang sehat, baik fisik, kimia, biologi, maupun sosial perlu adanya jaminan tersedianya lingkungan yang sehat dari Pemerintah daerah dan masyarakat, lingkungan yang sehat tersebut harus mencakup permukiman, tempat kerja, tempat rekreasi, serta tempat dan fasilitas umum serta bebas dari unsurunsur yang menimbulkan gangguan kesehatan, antara lain: limbah cair; limbah padat; limbah gas; sampah yang tidak diproses sesuai dengan persyaratan yang ditetapkan pemerintah; binatang pembawa penyakit; zat kimia yang berbahaya; kebisingan yang melebihi ambang batas; radiasi sinar pengion dan non pengion; air yang tercemar; udara yang tercemar; dan 
makanan yang terkontaminasi (Depkes RI, 2009).

Oleh sebab itu, masalah kesehatan lingkungan juga sangat perlu untuk diperhatikan, karena lingkungan dapat menyebabkan timbulnya berbagai macam penyakit salah satunya adalah penyakit malaria. Malaria merupakan salah satu masalah kesehatan masyarakat yang dapat menyebabkan kematian terutama pada kelompok risiko tinggi, yaitu bayi, anak balita, dan ibu hamil. Selain itu, malaria dapat secara langsung menyebabkan anemia dan menurunkan produktivitas kerja (Permenkes RI, 2012).

Pada tahun 2010 di Indonesia terdapat 65\% kabupaten endemis dimana hanya sekitar $45 \%$ penduduk di kabupaten tersebut berisiko tertular malaria. Berdasarkan hasil survei komunitas selama 2007 -2010, prevalensi malaria di Indonesia menurun dari 1,39\% (Riskesdas 2007) menjadi $0,6 \%$ (Riskesdas 2010). Berdasarkan laporan yang diterima selama tahun 2000-2009, angka kesakitan malaria mengalami penurunan yaitu sebesar 3,62 per 1.000 penduduk pada tahun 2000 menjadi 1,85 per 1.000 penduduk pada tahun 2009 dan 1,96 tahun 2010. Sementara itu, angka kematian akibat malaria sebesar 1,3\%. Berdasarkan data secara nasional, Annual Parasite Incidence (API) telah terjadi penurunan namun di daerah endemik malaria angka API masih sangat tinggi dibandingkan angka nasional, sedangkan pada daerah yang mempunyai kasus malaria rendah sering terjadi Kejadian Luar Biasa (KLB) sebagai akibat adanya kasus impor. Pada tahun 2011 jumlah kematian akibat penyakit malaria yang dilaporkan adalah 388 kasus. Prevalensi nasional malaria berdasarkan hasil Riskesdas tahun 2010 adalah 0,6\% dimana provinsi dengan API di atas angka ratarata nasional adalah Nusa Tenggara Barat, Maluku, Maluku Utara, Kalimantan Tengah, Bangka Belitung, Kepulauan Riau, Bengkulu, Jambi, Sulawesi Tengah, Gorontalo, dan Aceh. Tingkat prevalensi tertinggi ditemukan di wilayah timur Indonesia, yaitu di Papua Barat (10,6\%), Papua $(10,1 \%)$ dan Nusa Tenggara Timur $(4,4 \%)$.

Tujuan penelitian ini adalah untuk memodelkan hubungan antara kepadatan hunian dan perilaku menguras bak mandi dengan kejadian penyakit malaria di Indonesia.

\section{Metodologi Penelitian}

Penelitian ini merupakan penelitian non reaktif atau unobstrusive measures karena pada pengukuran variabel penelitian yang akan digunakan peneliti menggunakan data sekunder. Penelitian ini dilakukan pada bulan Juni tahun 2014. Data yang digunakan dalam penelitian ini adalah data sekunder yang diperoleh dari hasil Riset Kesehatan Dasar tahun 2013. Data yang digunakan dalam penelitian ini adalah data kejadian penyakit malaria (Y), Kepadatan Hunian (X1) dan Perilaku Menguras Bak Mandi (X2) pada 33 Provinsi di Indonesia.

Analisi data yang digunakan dalam penelitian ini adalah analisis regresi linier berganda. Tahapan analisis adalah melakukan uji asumsi analisis regresi linier berganda yang meliputi error harus berdistribusi normal, tidak ada masalah heteroskedastisitas, ada tidaknya masalah otokorelasi dan tidak ada masalah multikolinieritas. Setelah asumsi regresi terpenuhi, kemudian langkah selanjutnya adalah melakukan pengujian koefisien regresi yang meliputi pengujian secara keseluruhan dan pengujian parsial. Analisis regresi linier berganda pada penelitian ini menggunakan bantuan salah satu software di komputer. 
Hasil Penelitian Dan Pembahasan

\section{Deskripsi Variabel}

Descriptive Statistics

\begin{tabular}{|l|r|r|r|}
\hline & \multicolumn{1}{|c|}{ Mean } & \multicolumn{1}{|c|}{ Std. Deviation } & \multicolumn{1}{|c|}{$\mathbb{N}$} \\
\hline malaria &, 7485 & 1,31295 & 33 \\
kepdtan & 83,1424 & 9,03396 & 33 \\
perilaku & 30,5091 & 9,10214 & 33 \\
\hline
\end{tabular}

Tabel di atas menggambarkan nilai rata rata dan standar deviasi dari setiap variabel. Dari 33 propinsi yang ada di Indonesia diketahui bahwa rata rata angka kejadian malaria di setiap propinsi adalah 0,75 dengan simpangan deviasi sebesar 1,313. Rata rata kepadatan hunian adalah 83,14 dengan standar deviasi 9,03. Sementara itu perilaku menguras bak mandi rata rata 30,51 dan standar deviasi 9,10 .

\begin{tabular}{|ll|r|r|r|}
\hline & & \multicolumn{1}{c|}{ malaria } & kepdtan & perilaku \\
\hline Pearson Correlation & malaria & 1,000 &,- 613 &,- 334 \\
& kepdtan &,- 613 & 1,000 &, 540 \\
& perilaku &,- 334 &, 540 & 1,000 \\
\hline Sig. (1-tailed) & malaria & &, 000 &, 029 \\
& kepdtan &, 000 & &, 001 \\
& perilaku &, 029 &, 001 & \\
\hline $\mathrm{N}$ & malaria & 33 & 33 & 33 \\
& kepdtan & 33 & 33 & 33 \\
& perilaku & 33 & 33 & 33 \\
\hline
\end{tabular}

Tabel di atas menggambarkan korelasi di antara variabel. Korelasi tersebut menunjukkan derajat keeratan hubungan di antara dua variabel. Dari tabel tersebut diketahui bahwa ada korelasi negatif dan signifikan antara kejadian malaria dengan kepadatan hunian dengan nilai korelasi sebesar $-0,613$ dan ada korelasi negatif yang signifikan antara kejadian malaria dengan perilaku menguras bak mandi yaitu sebesar -0,334 Sementara nilai korelasi antara kepadatan hunian dan perilaku menguras bak mandi adalah 0,540. Korelasi negatif artinya korelasi antara kedua variabel tersebut bersifat berlawanan. Peningkatan nilai $X$ akan dibarengi dengan penurunan $\mathrm{Y}$ atau peningkatan kepadatan hunian akan menurunkan angka kejadian malaria dan peningkatan perilaku menguras bak mandi akan menurunkan angka kejadian malaria. Variables Entered/Removed ${ }^{\mathrm{b}}$

\begin{tabular}{|l|l|l|l|}
\hline Model & \multicolumn{1}{|c|}{$\begin{array}{c}\text { Variables } \\
\text { Entered }\end{array}$} & \multicolumn{1}{|c|}{$\begin{array}{l}\text { Variables } \\
\text { Removed }\end{array}$} & Method \\
\hline 1 & $\begin{array}{l}\text { perilaku, } \\
\text { kepdtan }\end{array}$ &. & Enter \\
\hline
\end{tabular}

Hasil Variable Entered menunjukkan bahwa kepadatan hunian dan perilaku menguras bak mandi adalah variabel yang akan dianalisis dan berperan sebagai variabel independen, sedangkan kejadian malaria adalah variabel dependen.

2. Uji asumsi

Berikut adalah tahap awal pemeriksaan terhadap hasil analisis regresi linier berganda. Tahap ini merupakan pemeriksaan terhadap pemenuhan asumsi, yaitu :

a. Pemeriksaan pertama : normalitas error ( error mengikuti fungsi distribusi normal)

Pemeriksaan normalitas error dapat dilihat dari beberapa hal yaitu distribusi histogram, Normal PP Plot of Regression Standardized Residual dan pengujian hipotesis standardized residual melalui Uji Kolmogorov Smirnov atau Shapiro Wilks. Penelitian ini menggunakan distribusi histogram dan Uji Kolmogorov-Smirnov.

Histogram

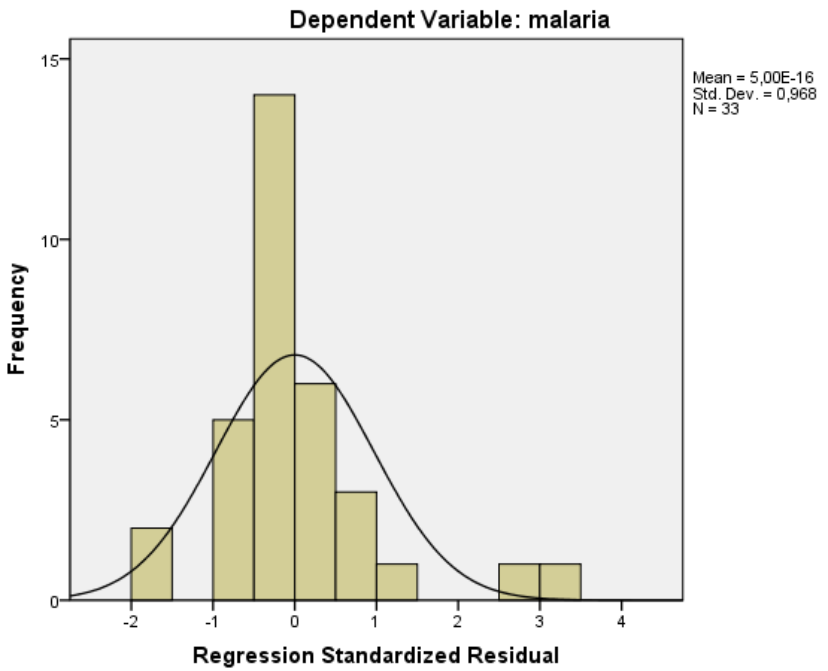

Gambar 1. Histogram dari variabel dependen kejadian malaria

Distribusi histogram mengikuti fungsi distribusi normal apabila berbentuk seperti bel. Dari grafik di atas, secara visual, kita bisa mengatakan bahwa distribusi histogram tersebut mengikuti distribusi normal. 
Untuk lebih meyakinkan kita perlu melakukan pengujian hipotesis melalui Uji Kolmogorov-Smirnov.

Hipotesisnya berbunyi :

$\mathrm{H}_{0}$ : Error berdistribusi normal

$\mathrm{H}_{1}$ : Error tidak berdistribusi normal

Kriteria pengujian : $\mathrm{H}_{0}$ diterima bila $p$ value hasil pengujian Uji Kolmogorov Smirnov lebih besar dari 5\% $(0,05)$

One-Sample Kolmogorov-Smirnow Test

\begin{tabular}{|ll|r|}
\hline & & $\begin{array}{c}\text { Standardized } \\
\text { Residual }\end{array}$ \\
\hline Normal Parameters & a,b & Mean \\
& Std. Deviation & 33 \\
Most Extreme Differences & Absolute &, 9000000 \\
& Positive &, 96824584 \\
& Negative &, 167 \\
Kolmogorow-Smirnov Z & &, 167 \\
Asymp. Sig. (2-tailed) & -139 \\
\hline \multicolumn{2}{|c|}{ a. Test distribution is Normal. } \\
b. Calculated from data.
\end{tabular}

Berdasarkan tabel di atas diketahi bahwa p-value Uji Kolmogorov Smirnov adalah 0,319>0,05. Dengan demikian dapat dikatakan bahwa H0 diterima. Oleh karena itu, asumsi error berdistribusi normal terpenuhi.

b. Pemeriksaan kedua : varians error konstan (tidak ada masalah heteroskedastisitas)

varians error konstan untuk setiap pengamatan disebut juga homoskedastisitas. Sebaliknya jika tidak konstan, maka disebut heteroskedastisitas. Untuk melihat varians error bersifat homoskedastisitas atau tidak ada masalah heteroskedastisitas dapat dilihat dari scatterplot. Varians error yang homoskedastisitas menyebar secara acak/normal tidak membentuk suatu pola tertentu.

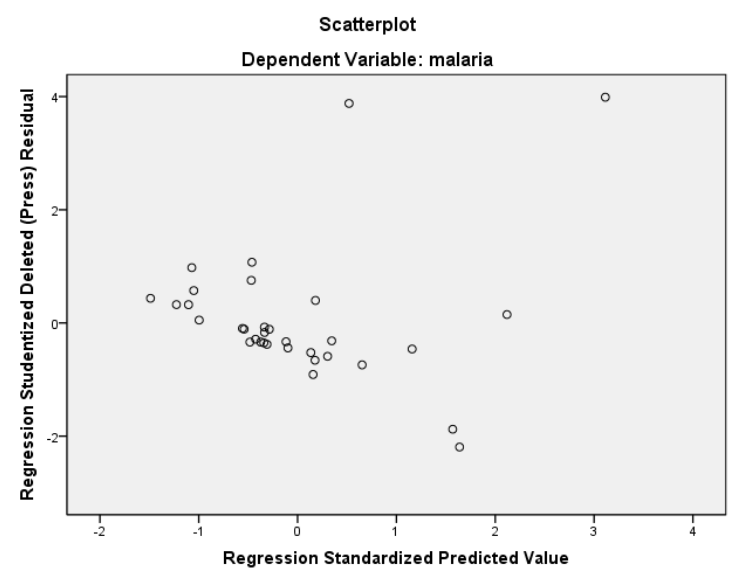

Gambar 2. Scatterplot dari variabel dependen kejadian malaria

Dari hasil pengujian dengan metode grafik scatterplot terlihat bahwa pencaran data bersifat acak dan tidak membentuk pola tertentu. Oleh karena itu dapat disimpulkan bahwa asumsi kedua terpenuhi.

c. Pemerikaan ketiga : pemeriksaan ada tidaknya masalah otokorelasi

pengujian ini dapat dilakukan melalui Run Test.

hipotesisnya berbunyi :

H0 : Tidak ada otokorelasi positif atau negatif H1 : Terdapat otokorelasi positif atau negatif Kriteria pengujian : $\mathrm{H}_{0}$ diterima bila $p$-value hasil pengujian Run Test lebih besar dari 5\% $(0,05)$

Runs Test

\begin{tabular}{|l|r|}
\hline & $\begin{array}{c}\text { Standardized } \\
\text { Residual }\end{array}$ \\
\hline Test Value $^{a}$ &,- 16733 \\
Cases $<$ Test Value & 16 \\
Cases $>=$ Test Value & 17 \\
Total Cases & 33 \\
Number of Runs & 15 \\
Z & -.703 \\
Asymp. Sig. (2-tailed) &, 482 \\
\hline
\end{tabular}

a. Median

Berdasarkan hasil Run Test diperoleh nilai $\mathrm{p}$ sebesar 0,482 >0,05 maka $\mathrm{H} 0$ diterima artinya tidak ada otokorelasi positif atau negatif. Oleh karena itu dapat disimpulkan bahwa asumsi ketiga terpenuhi.

d. Pemeriksaan keempat : tidak ada masalah multikolinieritas

pemeriksaan ini dapat dilihat dari nilai Variance Inflation Factor ( VIF ), TOL dan 
Condition Index. Nilai VIF > 10 menunjukkan adanya gejala multikolinieritas. Nilai Condition Index melebihi 30 menunjukkan adanya gejala multikolinieritas.

Hasil VIF dalam penelitian ini adalah sebagai berikut :

\begin{tabular}{|c|c|c|c|c|c|c|c|c|}
\hline \multicolumn{9}{|c|}{ Coefficients ${ }^{\beth}$} \\
\hline \multirow[b]{2}{*}{ Mode } & & \multicolumn{2}{|c|}{ Unstandardized Coefficients } & \multirow{2}{*}{$\begin{array}{c}\begin{array}{c}\text { Standardized } \\
\text { coefficients }\end{array} \\
\text { Beta }\end{array}$} & \multirow[b]{2}{*}{$\mathrm{t}$} & \multirow[b]{2}{*}{ Sig. } & \multicolumn{2}{|c|}{ Collinearity Statistics } \\
\hline & & $B$ & Std. Error & & & & Tolerance & VIF \\
\hline \multirow[t]{3}{*}{1} & (Constant) & 8,141 & 1,791 & & 4,545 & .000 & & \\
\hline & kepdtan &,- 089 & .025 &,- 610 & $-3,559$ & ,001 & .708 & 1,412 \\
\hline & perilaku &,- 001 & .025 & -004 &,- 025 & .980 & .708 & 1,412 \\
\hline
\end{tabular}

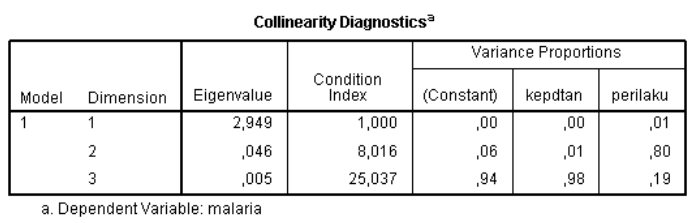

Berdasarkan tabel di atas, nilai VIF untuk variabel kepedatan hunian dan perilaku menguras bak mandi adalah $1,412<10$. Sementara nilai Condition Index maximum adalah 25,037 < 30. Dengan demikian, dapat dikatakan bahwa tidak terdapat masalah multikolinieritas. Oleh karena itu dapat disimpulkan bahwa asumsi keempat terpenuhi.

Setelah asumsi regresi terpenuhi, langkah selanjutnya adalah melakukan pengujian koefisien regresi yang meliputi

\begin{tabular}{|c|c|c|c|c|c|c|c|c|}
\hline \multicolumn{9}{|c|}{ Coefficients $^{a}$} \\
\hline \multirow[b]{2}{*}{ Mod } & & \multicolumn{2}{|c|}{ Unstandardized Coefficients } & \multirow{2}{*}{$\begin{array}{c}\text { Standardized } \\
\text { Coefficients }\end{array}$} & \multirow[b]{2}{*}{$t$} & \multirow[b]{2}{*}{ Sig. } & \multicolumn{2}{|c|}{ Collinearity Statistics } \\
\hline & & $\mathrm{B}$ & Std. Error & & & & \begin{tabular}{|l|l} 
Tolerance \\
\end{tabular} & VIF \\
\hline \multirow[t]{3}{*}{1} & (Constant) & 8,141 & 1,791 & & 4,545 & .000 & & \\
\hline & kepdtan & -0089 & .025 &,- 610 & $-3,559$ & 001 & .708 & 1,412 \\
\hline & perilaku &,- 001 & .025 &,- 004 &,- 025 & .980 & .708 & 1,412 \\
\hline
\end{tabular}

a. Pengujian secara keseluruhan

pengujian secara keseluruhan menggunakan statistik $\mathrm{F}$ dalam tabel ANOVA, dengan hipotesis sebagai berikut : $\mathrm{H}_{0}$ : Secara bersama-sama, kepadatan hunian dan perilaku menguras bak mandi tidak mempunyai pengaruh yang signifikan terhadap kejadian malaria.

$\mathrm{H}_{1}$ : Minimal terdapat satu variabel kepadatan hunian atau perilaku menguras bak mandi yang berpengaruh signifikan terhadap kejadian malaria.

Hasil yang di dapat dalam penelitian ini adalah sebagai berikut :

\begin{tabular}{|c|c|c|c|c|c|c|}
\hline \multicolumn{7}{|c|}{ ANOVA ${ }^{\text {b }}$} \\
\hline Model & & $\begin{array}{c}\text { Sum of } \\
\text { Squares }\end{array}$ & df & Mean Square & $\mathrm{F}$ & Sig. \\
\hline \multirow[t]{3}{*}{1} & Regression & 20,701 & 2 & 10,350 & 9,010 & $.001^{3}$ \\
\hline & Residual & 34,462 & 30 & 1,149 & & \\
\hline & Total & 55,162 & 32 & & & \\
\hline
\end{tabular}

Berdasarkan tabel di atas p-value statistik $\mathrm{F}$ adalah $0,001<0,05$, maka kita menolak H0 dan menerima $\mathrm{H} 1$ yang artinya minimal terdapat satu variabel kepadatan hunian atau perilaku menguras bak mandi yang berpengaruh signifikan terhadap kejadian malaria.

b. Pengujian secara individual ( parsial )

pengujian secara individual atau parsial menggunakan statistik $\mathrm{t}$ dengan tingkat kesalahan (alpha) 5\% dengan hipotesisnya adalah :

$\mathrm{H}_{0}$ : kepadatan hunian tidak berpengaruh signifikan terhadap kejadian malaria

$\mathrm{H}_{1}$ : kepadatan hunian berpengaruh signifikan terhadap kejadian malaria

Atau

$\mathrm{H}_{0}$ : perilaku menguras bak mandi tidak berpengaruh signifikan terhadap kejadian malaria

$\mathrm{H}_{1}$ : perilaku menguras bak mandi berpengaruh signifikan terhadap kejadian malaria

Hasil dari penelitian ini adalah sebagai berikut

Berdasarkan hasil pengujian secara parsial didapatkan bahwa $p$-value untuk kepadatan hunian adalah $0,001>0,05$ artinya kepadatan hunia berpengaruh signifikan terhadap kejadian malaria dan $p$-value untuk perilaku menguras bak mandi adalah 0,980 > 0,05 yang artinya perilaku menguras bak mandi tidak berpengaruh terhadap kejadian malaria.

Besarnya persentase keseluruhan pengaruh kepadatan hunian dan perilaku menguras bak mandi terhadap kejadian malaria dapat dilihat dari nilai $\mathrm{R}$ Square berikut ini :

\begin{tabular}{|l|l|l|c|c|}
\hline Model & $\mathrm{R}$ & $\mathrm{R}$ Square & $\begin{array}{c}\text { Adjusted R } \\
\text { Square }\end{array}$ & $\begin{array}{c}\text { Std. Error of } \\
\text { the Estimate }\end{array}$ \\
\hline 1 &, $613^{\mathrm{a}}$ &, 375 &, 334 & 1,07179 \\
\hline
\end{tabular}

Artinya, kepadatan hunian dan perilaku menguras bak mandi menjelaskan variabilitas variabel kejadian malaria sebesar $37,5 \%$, sedangkan $62,5 \%$ dijelaskan oleh variabel lainnya.

Model regresi yang terbentuk adalah :

$\mathrm{Y}=8,141-0,089$ kepadatan hunian $-0,001$ perilaku menguras bak mandi. 
Artinya, setiap kenaikan atau bertambahnya 1 kepadatan hunian akan menurunkan kejadian malaria sebesar 0,089 dan setiap kenaikan atau bertambahnya 1 perilaku menguras bak mandi akan menurunkan kejadian malaria sebesar 0,001.

Penelitian ini hanya menjelaskan 37,5\% terhadap kejadian malaria, namun tidak menutup kemungkinan untuk melakukan pencegahan terhadap penyakit malaria terutama dalam hal kepadatan hunian dan perilaku menguras bak mandi. Sampai saat ini penyakit malaria masih menjadi masalah kesehatan di Indonesia. Berbagai upaya pencegahan dilakukan untuk menekan angka kesakitan dan kematian. Kegiatan tersebut dilakukan dengan program pemberantasan malaria yang meliputi penemuan kasus secara dini, pengobatan yang tepat cepat, surveilans dan pengendalian vektor dalam hal penyuluhan kesehatan kepada masyarakat dan pentingnya kesehatan lingkungan, yang bertujuan untuk memutus mata rantai penularan malaria. Pemerintah bahkan telah mengeluarkan pedoman tatalaksana malaria, diharapkan masyarakat mengetahui dan mengerti tentang penyakit malaria, tanda dan gejalanya, komplikasinya dan pencegahannya (Permenkes RI, 2012).

Salah satu faktor yang menyebabkan penyakit malaria dapat berkembang dengan cepat adalah faktor dari kesehatan lingkungan. Lingkungan mempunyai pengaruh besar terhadap perkembangbiakan nyamuk Anopheles $s p$., sehingga pengetahuan dan wawasan tentang kesehatan lingkungan kepada masyarakat perlu mendapat perhatian yang lebih dalam upaya pencegahan penularan penyakit malaria. Masyarakat harus lebih memahami arti pentingnya kesehatan lingkungan, baik lingkungan di dalam rumah maupun di luar rumah. Lingkungan di dalam rumah, misalnya kondisi fisik rumah dengan memperhatikan penerangan, ventilasi, suhu lingkungan, tersedianya air bersih, tersedianya tempat pembuangan air limbah, dan dapat melindungi anggota keluarga yang didalamnya dari kecelakaan. Lingkungan di luar rumah, misalnya jarak rumah dari tempat tinggal dan tempat perindukan yang disenangi nyamuk Anopheless seperti adanya semak rimbun yang menghalangi sinar matahari menembus permukaan tanah, sehingga lingkungan menjadi teduh serta lembab, parit atau selokan yang digunakan untuk pembuangan limbah merupakan tempat berkembang biak yang disenangi nyamuk, dan kandang ternak sebagai tempat istirahat nyamuk sehingga populasi nyamuk bertambah (Handayani dkk, 2008).

Salah satu upaya pencegahan penyakit malaria adalah upaya promotif melalui penyuluhan kesehatan masyarakat, dan tujuan akhir dari penyuluhan kesehatan masyarakat adalah diharapkan adanya perubahan perilaku yang awalnya belum sehat menjadi perilaku yang lebih sehat, artinya perilaku yang mendasarkan pada prinsip - prinsip sehat atau kesehatan. Penyuluhan kesehatan yang diberikan kepada masyarakat harus direncanakan dengan menggunakan strategi yang tepat disesuaikan dengan sasaran dan permasalahan kesehatan yang ada. Strategi yang dapat dilakukan meliputi metode atau cara yang digunakan, pendekatan sosial dan teknik yang dapat digunakan untuk mempengaruhi faktor pendukung dan penguat yang secara langsung atau tidak langsung dapat mengubah perilaku masyarakat (Machfoedz dkk, 2005).

Penyuluhan kesehatan yang dilakukan harus sesuai dengan kebutuhan masyarakat dan tepat sasaran, hal ini akan lebih mudah diterima jika menggunakan alat bantu yang disebut peraga. Alat bantu ini bisa dalam bentuk poster atau gambar. Pengetahuan masyarakat akan semakin banyak dan jelas jika indra yang digunakan juga banyak, yang meliputi penglihatan, pendengaran dan penciuman. ( Depkes RI, 1999). 


\section{Kesimpulan}

1. Asumsi regresi linier berganda yang meliputi error mengikuti fungsi dsitribusi normal, varians error konstan atau varians error bersifat homoskedastisitas, tidak ada masalah otokorelasi atau variabel di antara pengamatan error bersifat independen dan tidak ada masalah multikolinieritas di antara variabel independen terpenuhi

2. Hasil uji keseluruhan dengan menggunakan Statistik $\mathrm{F}$ didapatkan nilai $\mathrm{p}=0,001<0,05$ (alpha) artinya minimal ada satu variabel kepadatan hunian atau perilaku menguras bak mandi yang berpengaruh signifikan terhadap kejadian penyakit malaria.

3. Hasil uji sebagian dengan menggunakan Statistik $\mathrm{t}$ didapatkan nilai $p$ untuk variabel kepadatan hunian adalah $0,001<0,05$ artinya kepadatan hunian berpengaruh terhadap kejadian penyakit malaria dan nilai $\mathrm{p}$ untuk variabel perilaku menguras bak mandi adalah $0,980>0,05$ artinya perilaku menguras bak mandi tidak berpengaruh terhadap kejadian penyakit malaria.

4. Model regresi yang terbentuk adalah : Kejadian Penyakit Malaria $=8,141-$ 0,089 kepadatan hunian $-0,001$ perilaku menguras bak mandi.

\section{Daftar Pustaka}

Badan Penelitian dan Pengembangan Kesehatan Kemenkes RI. 2008. Riset Kesehatan Dasar 2007. Jakarta : Kementerian Kesehatan RI

Badan Penelitian dan Pengembangan Kesehatan Kemenkes RI. 2010. Riset Kesehatan Dasar 2010. Jakarta : Kementerian Kesehatan RI

Badan Penelitian dan Pengembangan Kesehatan Kemenkes RI. 2013. Riset Kesehatan Dasar 2013. Jakarta : Kementerian Kesehatan RI
Dapper dan Smith (1992) Analisis Regresi Terapan, Jakarta : Gramedia Pustaka

Depkes RI, 2009. Undang Undang tentang Kesehatan. Jakarta : Depkes RI

Depkes RI. 1999. Modul Manajemen Pemberantasan Penyakit Malaria 6. Jakarta: Depkes RI

Gujarati, N.D. 2003. Basic Econometrics. New York : McGraw-Hill Companies, Inc.

Handayani L., Pebrorizal., Soeyoko. Faktor Risiko Penularan Malaria Vivak. Berita Kedokteran Masyarakat. Vol. 24. No. 1. Maret 2008:38-43.

Kemenkes RI. 2012. Pedoman Penatalaksanaan Kasus Malaria. Jakarta : Kementerian Kesehatan RI

Kemenkes RI. 2014. Profil Kesehatan Indonesia 2013. Jakarta : Kementerian Kesehatan RI

Kutner, M.H., C.J.Nachtsheim., dan J. Neter. 2004. Applied Linear Regression Models. New York : McGraw-Hill Companies, Inc.

Machfoedz I., Suryani E., Sutrisno., Santosa S. 2005. Pendidikan Kesehatan Bagian dari Promosi Kesehatan. Yogyakarta: Fitramaya

Romadhon Y. 2001. Hubungan Beberapa Faktor Lingkungan dengan Kejadian Malaria di Kecamatan Salaman Kabupaten Magelang. Semarang: FKM UNDIP. 